\title{
629 乗員のダイナミクスを考慮したサスペンション制御系設計 \\ Robust Active Suspension Control for Vibration Reduction of Passenger's Body
}

\author{
○正 鈴木 卓馬 (慶大院) 正 高橋 正樹 (慶應大)
}

Takuma SUZUKI, Keio University, 3-14-1, Hiyoshi, Kohoku-ku, Yokohama

Masaki TAKAHASHI, Keio University

\begin{abstract}
In recent years, it is reported that passenger's dynamics and vibration characteristics. However there are few researches about the suspension control which considered these dynamics of human body characteristics and sitting position. In this paper, a vehicle and passenger system including the dynamics of human body at sitting position is constructed, and the robust control system design which sets the vertical acceleration of a passenger's head to one of the amounts of evaluation function is proposed. As the result, it was confirmed that in nearly the resonance frequency of a passenger's head, the proposed control system is effective in reducing a passenger's vibration better than the general control system of having made vertical vehicles acceleration the valuation function.
\end{abstract}

Key word: Active Suspension, Vehicle dynamics, Robust Control, Ride comfort, Passenger's dynamics,

\section{A 1. 精}

自動車の乗心地向上のため,これまでに多くのデバイス手 法が提案され, その多くは車体重心の上下加速度の低減を目 指してきた。しかし，必ずしも乗員は車体の重心に着座して いるわけでなく, 乗員自身もダイナミクスを持ち, サスペン ションの共振周波数とは異なる周波数帯域でも乗員は大き く振られ，振動を強く感じる. 本研究では, アクティブサス ペンションを用いて，乗員の着座位置および乗員自身のダイ ナミクスを考慮し, 乗員の頭部上下加速度を低減する手法(手 法 C)を提案し, 従来の車体重心の上下加速度を指標とした手 法(手法 A), 着座位置の上下加速度を指標とした手法(手法 B)に対して，提案手法が限られた消費エネルギーで最も乗員 の動きを減らす効果があることを示す.

\section{A 2. 車両と乗員のモデル化}

乗員のダイナミクスを制御系設計に踏まえるため, 頭部と 胴体からなる 6 自由度(一名あたり)の乗員モデルを，ばね下 と車体からなる 7 自由度の車両モデルに組込み 13 自由度か らなる車両-乗員モデル(Fig.A1)を構築した.

\section{A 3. 外乱包含 Ho制御}

ばね上共振は $1 〜 2 \mathrm{~Hz}$ ，乗員頭部(上下)の共振は $4 \sim 6 \mathrm{~Hz}$, ばね下共振は 10 数 $\mathrm{Hz}$ と各周波数帯域が異なり, 路面振幅の PSD も高周波で低下する特性を制御系設計に踏まえるため, 外乱包含 Hoo制御を用いた．車両-乗員モデルに, 外乱と制御 量に対して周波数重みを設けた拡大系において, 提案手法(手 法 C) は乗員の上下加速度を制御量として，H制御器の導出 をした．なお比較のため, 乗員頭部の上下加速度(手法 C)の 代わりに, 車体重心の上下加速度(手法 A), 着座位置の上下 加速度(手法 B)をそれぞれ制御量とし，四輪のアクティブサス ペンションが発生する推力の絶対值の和の RMS が同一となるよ うに, それぞれの制御器を設計した.

\section{A 4. シミュレーション}

ISO-8608 で定義されたC クラス相当の路面を直進走行し， 提案手法(手法 C) と, 手法 A, B との比較を行った. その結 果, 頭部の共振がある 4 8Hzの帯域においては, 手法 C が最 も制振効果が高いにも関わらず(Fig.A2(a)), 推力の PSD は同 周波数帯域においては必ずしも最も推力が高いわけではなく (Fig.A2(b))、従来手法(手法 A,B)に比べ同周波数域において 限られた推力で制御効果を出すことができる。

\section{A 5. 結要}

本研究では, アクティブサスを用いて, 路面の凹凹による乗員 の動きを低減させることを目的とし, 乗員のダイナミクスを含む車 両-乗員系を構築し, 乗員(助手席)の頭部の上下加速度を評価 量のひとつとする制御系を提案し，従来手法に比べ, アクチュエ 一タが発生する単位推力(RMS ベース)に対する制御効果が大き く, 消費エネルギー的にも効率の良い制御手法であり, その有効 性を示すことができた。

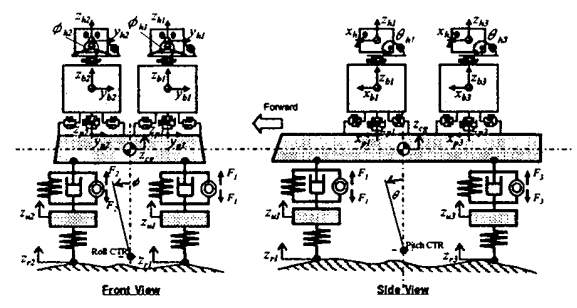

Fig.A1 Vehicle-Passenger Model

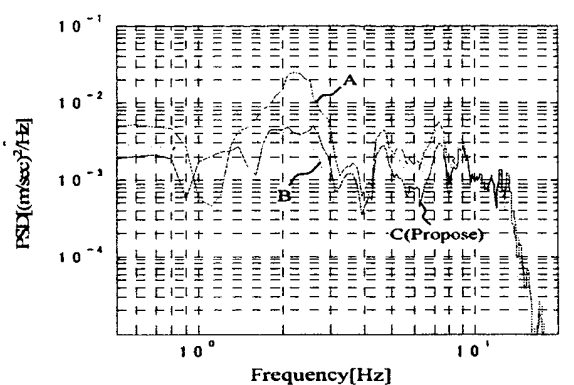

(a) Vertical Acceleration (Passenger 1' head)

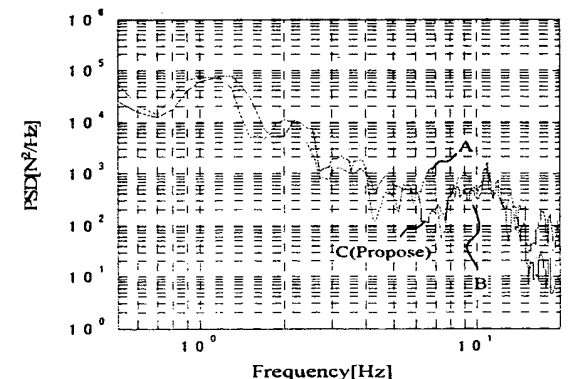

(b) Actuator force

Fig.A2 Power spectral Density

日本機械学会〔No.09-23］Dynamics and Design Conference 2009 CD-ROM 論文集〔2009.8.3-8,札幌〕 


\section{1. 粕}

自動車のさらなる乗心地向上は，永遠の課題であり，こ れまでに多くの制御デバイスと制御手法により，乗心地向 上策が示され，車体の振動レベル低減量，主に路面凹凸に 対する車体の重心位置の上下加速度でその効果が議論され てきた 1 33なと多攻。しかし，実際の乗員の着座位置は必ずし も車体の重心ではなく, 着座位置にはロールやピッチの回 転運動による上下方向の加速度が生じシートの弾性特性, さらには乗員自身のダイナミクスにより乗員の動きは車体 の動きよりも大きくなり，それらを踏まえた制御系設計が 重要である.

これまでの乗員の振動特性に関する研究では，さまざま な着座姿勢において, 着座位置の前後, 左右, 上下などの 多方向からの振動入力に対する人間の振動特性を奏験的に 明らかにし，これらの結果を元にした乗員とシートのモデ ル化 ${ }^{4)}$ やドライバと乗員の振動感受特性に差があることな ど, 乗員の感性に関する研究 ${ }^{5)}$ も行われ, 乗員の振動特性 は解明されつつある。

一方, 乗員-車両系に関する研究では，簡単な乗員モデル を用いて路面の凹凸に対して，通常の車両(制御サスを搭載 しない車両)に乗車した乗員の動きを解析した研究 ${ }^{6} や$ や乗 員の着座位置を踏まえ車体の振動低減を犋った研究 ${ }^{7)}$, さら には車体の振動を抑える制御手法の効果を乗員モデルの動

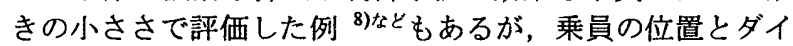
ナミクス(振動特性)を積極的に踏まえたアクティブサスペ ンションの制御系設計を試みた研究はなく，乗員のダイナ ミクスを踏まえた制御系設計を行うことでより乗員の動き を减らす効果が期待できる. 特に乗員頭部の上下方向の共 振は，車両のばね上および下の共振周波数とはことなるこ となる周波数にあり，単にスカイフック制御などにより車 両のそれら共振周波数近傍の振動レベルを下げるだけでは， 乗員の共振周波数近傍の動きを抑えることはできない.

本研究では，これら先行研究の乗員のダイナミクスを踏 まえアクティブサスペンションを用いて，路面の凹凸によ る乗員の動きをより低減させることを目的とし，乗員のダ イナミクスを含む車両-乗員系を構築し, 乗員(助手席)の頭 部の上下加速度を評価量のひとつとする制御系を提案する。 アクティブサスペンションの制御において, 燃費性能との トレードオフを踏まえ，限られた消費エネルギーで乗員の 動きをいかに減らすことが重要である，本研究では，従来 の車体重心の上下加速度を評価量とする手法(手法 A)やシ 一ト位置での上下加速度を評価量とする手法(手法 B) と本 提案手法(手法 C)の比較を行い, 本提案手法がアクチュエー 夕が発生する単位推力(RMS ベース)に対し, 制御効果(乗員 の頭部加速度の低減代)が高く，消費エネルギー的にも効率 の良い制御手法であることを示す。

\section{2. モデリング}

\section{1 車両モデル}

制御対象の一部である車両モデルは, Fig.1 に示すフルビ 一クルモデルであり，車体とばね下の間にフルアクティブ サスペンション(カ発生装置)を備える. 本モデルの四輪のば ね下(上下 4 自由度), 車体ばね上(バウンス，ロール，ピッ チ)の計 7 自由度の運動方程式は次のとおりである. 各パラ メータは Table 1 のとおりである.

$$
\begin{aligned}
M_{b} \ddot{Z}_{c g}= & -K_{f} Z_{s 1}-C_{f} \dot{Z}_{s 1}+F_{1}-K_{f} Z_{s 2}-C_{f} \dot{Z}_{s 2}+F_{2} \\
& -K_{r} Z_{s 3}-C_{r} \dot{Z}_{s 3}+F_{3}-K_{r} Z_{s 4}-C_{4} \dot{Z}_{s 4}+F_{4} \\
I_{r} \ddot{\phi}= & T_{f} / 2\left[-K_{f}\left(Z_{s 1}-Z_{s 2}\right)-C_{f}\left(\dot{Z}_{s 1}-\dot{Z}_{s 2}\right)+\left(F_{1}-F_{2}\right)\right] \\
& T_{r} / 2\left[-K_{r}\left(Z_{s 3}-Z_{s 4}\right)-C_{r}\left(\dot{Z}_{s 3}-\dot{Z}_{s 4}\right)+\left(F_{3}-F_{4}\right)\right]+M_{b} g H_{r} \phi \\
I_{p} \ddot{\theta}= & -L_{f}\left(-K_{f} Z_{s 1}-C_{f} \dot{Z}_{s 1}+F_{1}-K_{f} Z_{s 2}-C_{f} \dot{Z}_{s 2}+F_{2}\right) \\
& +L_{r}\left(-K_{r} Z_{s 3}-C_{r} \dot{Z}_{s 3}+F_{3}-K_{r} Z_{s 4}-C_{4} \dot{Z}_{s 4}+F_{4}\right)+M_{b} g H_{p} \theta \\
M_{t} \ddot{Z}_{u i}= & K_{t} Z_{t t}-F_{t}-K_{f} Z_{s t}-C_{f} \dot{Z}_{s t} \quad(i=1,2) \\
M_{t i} \ddot{Z}_{u i}= & K_{t} Z_{t 1}-F_{1}-K_{r} Z_{s i}-C_{r} \dot{Z}_{s t} \quad(i=1,2)
\end{aligned}
$$

ここで， $H_{r}$ はロールセンタからばね上重心までの距離, $H_{p}$ はピッチセンタからばね上重心までの距離であり，共に 固定とし， $Z_{s i}$ は各輪のサスペンションストローク， $Z_{i i}$ は各 輪のタイヤたわみを意味し，次式で与える.

$$
\begin{aligned}
& Z_{s 1}=Z_{c g}+T_{f} / 2 \phi-L_{f} \theta-Z_{u 1} \\
& Z_{s 2}=Z_{c g}-T_{f} / 2 \phi-L_{f} \theta-Z_{u 2} \\
& Z_{s 3}=Z_{c g}+T_{r} / 2 \phi+L_{r} \theta-Z_{u 3} \\
& Z_{s 4}=Z_{c g}-T_{r} / 2 \phi+L_{r} \theta-Z_{u 4} \\
& Z_{t i}=Z_{r i}-Z_{u i}(i=1 \cdots 4)
\end{aligned}
$$
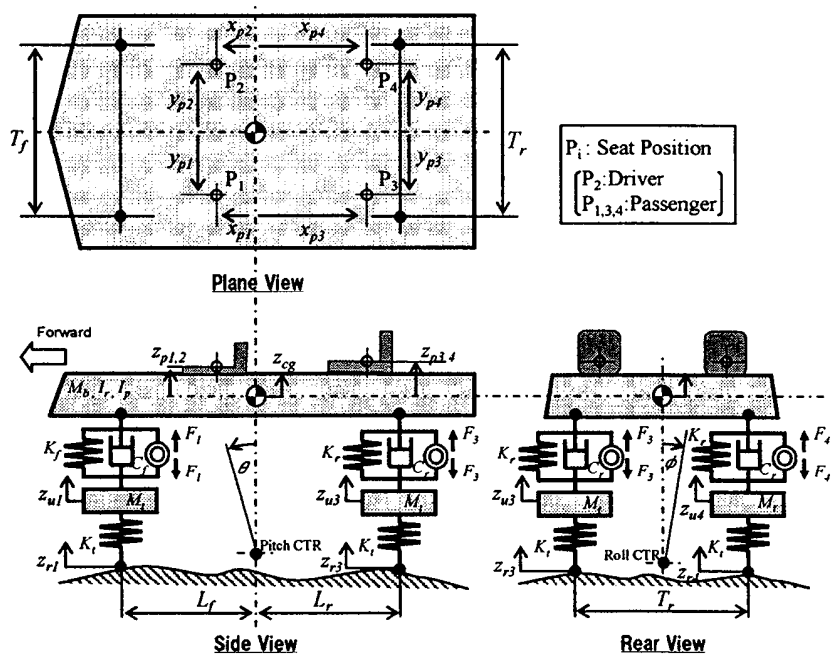

Fig.1 Full Vehicle Model

Table 1 Specification of Vehicle model

\begin{tabular}{c|rl|c|cc}
\hline \multicolumn{3}{c|}{ Symbol } & \multicolumn{2}{|c|}{ Value } & \multicolumn{2}{|c}{ Symbol } & \multicolumn{2}{|c}{ Value } \\
\hline$M_{b}$ & 1900 & $\mathrm{~kg}$ & $l_{f}$ & 1.34 & $\mathrm{~m}$ \\
$M_{t}$ & 50 & $\mathrm{~kg}$ & $l_{r}$ & 1.46 & $\mathrm{~m}$ \\
$I_{r}$ & 600 & $\mathrm{kgm}^{2}$ & $T_{f}$ & 1.53 & $\mathrm{~m}$ \\
$I_{p}$ & 3000 & $\mathrm{kgm}^{2}$ & $T_{r}$ & 1.50 & $\mathrm{~m}$ \\
$K_{f}$ & $33 \times 10^{3}$ & $\mathrm{~N} / \mathrm{m}$ & $h_{r}$ & 0.45 & $\mathrm{~m}$ \\
$K_{r}$ & $31 \times 10^{3}$ & $\mathrm{~N} / \mathrm{m}$ & $h_{p}$ & 0.53 & $\mathrm{~m}$ \\
$K_{t}$ & $260 \times 10^{3}$ & $\mathrm{~N} / \mathrm{m}$ & $x_{p l .2}$ & 0.04 & $\mathrm{~m}$ \\
$C_{f}$ & 300 & $\mathrm{~N} / \mathrm{m} / \mathrm{s}$ & $x_{p 3.4}$ & 0.97 & $\mathrm{~m}$ \\
$C_{r}$ & 300 & $\mathrm{~N} / \mathrm{m} / \mathrm{s}$ & $y_{p i}$ & 0.4 & $\mathrm{~m}$ \\
& & & $z_{p l, 2}$ & -0.045 & $\mathrm{~m}$ \\
& & & $z_{p 3.4}$ & 0.015 & $\mathrm{~m}$ \\
\hline
\end{tabular}




\section{2 乗界モデル}

これまでに人間の着座姿勢でのモデル化は，着座位置の上 下方向に対する頭部の上下方向を表現したモデル ${ }^{9} や ，$ 頭部 の回転運動も直列ばねを用いて表現したモデル10)庆ともある. 本研究では着座位置の動きに対して乗員の動きをある程度 表現させることが可能で，その動きをイメージしやすいモデ ルとして, Fig.2 のモデルを考える.

胴体および頭部に慣性を持ち, 胴体は着座位置の点 Ps と の間に, 前後, 左右, 上下のばね/ダンパを持つ 3 自由度, 頭 部も胴体に対して上下, 点 $P r$ 回りにロール, 点 $P p$ 回りにピ ッチ運動をする 3 自由度, 計 6 自由度をもつモデルである. なお脚部は簡単のため省略した．乗員モデルの運動方程式は， 式(3)となる。

$$
\begin{aligned}
& m_{b h} \ddot{x}_{b}=2 k_{p 4}\left(x_{p}-x_{b}\right)+2 c_{p 4}\left(\dot{x}_{p}-\dot{x}_{b}\right) \\
& +k_{p 6}\left(z_{p}-x_{b}\right)+c_{p 6}\left(\dot{z}_{p}-\dot{x}_{b}\right)+\left(-c_{p 2} \dot{\theta}_{h}-k_{p 2} \theta_{h}\right) / r_{4} \\
& m_{b h} \ddot{y}_{b}=2 k_{p s}\left(y_{p}-y_{b}\right)+2 c_{p s}\left(\dot{y}_{p}-\dot{y}_{b}\right)-\left(-c_{p 7} \dot{\phi}_{h}-k_{p>} \phi_{h}\right) / r_{s} \\
& m_{b} \ddot{z}_{b}=k_{p 3}\left(z_{p}-z_{b}\right)+c_{p 3}\left(\dot{z}_{p}-\dot{z}_{b}\right)-\left[k_{p 1}\left(z_{b}-z_{h}\right)+c_{p 1}\left(\dot{z}_{b}-\dot{z}_{h}\right)\right] \\
& +\left(-c_{p 2} \dot{\theta}_{h}-k_{p 2} \theta_{h}\right) / r_{3} \\
& m_{h} \ddot{z}_{h}=k_{p 1}\left(z_{b}-z_{h}\right)+c_{p 1}\left(\dot{z}_{b}-\dot{z}_{h}\right)-\left(-c_{p 2} \dot{\theta}_{h}-k_{p 2} \theta_{h}\right) / r_{3} \\
& I_{h p} \ddot{\theta}_{h}=\left\{\left(-c_{p 2} \dot{\theta}_{h}-k_{p 2} \theta_{h}\right)+\left[k_{p 1}\left(z_{b}-z_{h}\right)+c_{p 1}\left(\dot{z}_{b}-\dot{z}_{h}\right)\right] r_{3}\right\} \\
& -m_{h b h} r_{2}\left\{\begin{aligned}
2 k_{p 4}\left(x_{p}-x_{b}\right) & +2 c_{p 4}\left(\dot{x}_{p}-\dot{x}_{b}\right)+k_{p 6}\left(z_{p}-x_{b}\right) \\
& +c_{p 6}\left(\dot{z}_{p}-\dot{x}_{b}\right)+\left(-c_{p 2} \dot{\theta}_{h}-k_{p 2} \theta_{h}\right) / r_{4}
\end{aligned}\right\} \\
& I_{h r} \ddot{\phi}_{h}=\left[-c_{p 7} \dot{\phi}_{h}-k_{p\urcorner} \phi_{h}\right]+m_{h b h} r_{1}\left\{\begin{array}{r}
2 k_{p s}\left(y_{p}-y_{b}\right)+2 c_{p s}\left(\dot{y}_{p}-\dot{y}_{b}\right) \\
-\left(-c_{p 7} \dot{\phi}_{h}-k_{p 7} \phi_{h}\right) / r_{5}
\end{array}\right\} \\
& \text { ここで、 } m_{b h}=m_{b}+m_{h}, \quad m_{h b h}=\frac{m_{h}}{\left(m_{b}+m_{h}\right)}
\end{aligned}
$$

乗員モデルの各パラメータは, 成人男性の身長および体重 データなどから $m_{b}=45[\mathrm{~kg}], m_{h}=7.5[\mathrm{~kg}], I_{h r}=8.3 \times 10^{-2}\left[\mathrm{kgm}^{2}\right]$, $I_{h p}=5.5 \times 10^{-2}\left[\mathrm{kgm}^{2}\right]$ とし, 先行研究で示された実験データ (Fig.3,4) $\left.{ }^{10},{ }^{11}\right)$ と本モデルの傾向が一致するようにばね, ダン パおよび長さの值を調整した(Table 2). なお，乗員頭部の重 心点の前後および横方向の加速度は, 胴体部の前後および上 下，頭部のピッチおよびロールの幾何学的な関係，式(4)より 算出している.

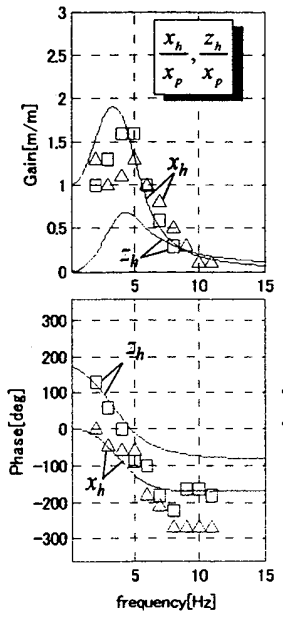

(a) $x_{p}$ input
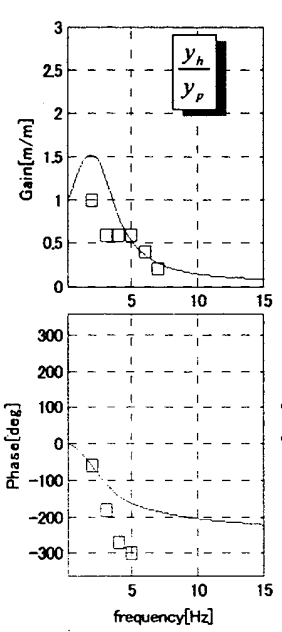

(b) $y_{p}$ input
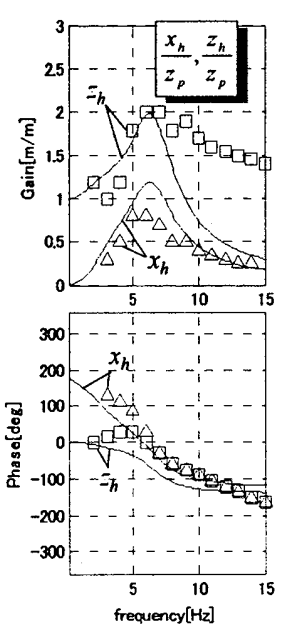

(c) $z_{p}$ input
Fig. 3 Transfer function from seat to the head (Translational motion, dot: Experiment ${ }^{\text {9) }}$, Line: Model)

$$
\begin{aligned}
& \ddot{x}_{h}=\ddot{x}_{b}+\ddot{\theta}_{h} / r_{2} \\
& \ddot{y}_{h}=\ddot{y}_{b}-\ddot{\phi}_{h} / r_{1}
\end{aligned}
$$

\section{3 莗両一乗员モデル}

本研究では，まず前の左席に着座する乗員の動き低減を実 現するため, 先の車両モデルに前も左席に本乗員モデルを配 置し, Fig.5 に示す車両-乗員モデルを構筑する. なお，後記 のシミュレーションにおいては，2 名乗車したモデルにおい て数値計算を行うが, 制御系設計においては 1 名乗車のモデ ルを用いている．着座位㯰の点 $\mathrm{P}_{s 1}$ の並進運動 $x_{p l}, y_{p l}, z_{p l}$ と車 体重心の上下 $z_{c g}$, ロール $\phi$, ピッチ $\theta$ には下記の関係があり， 車両の運動による乗員の動きを求めることができる.

Table 2 Specification of Passenger model

\begin{tabular}{c|ccc}
\hline & $k_{p i}$ & $c_{p i}$ & $r_{p i}$ \\
$i$ & {$[\mathrm{~N} / \mathrm{m}]$} & {$[\mathrm{N} / \mathrm{m} / \mathrm{s}]$} & {$[\mathrm{m}]$} \\
\hline 1 & 40000 & 2000 & 0.1 \\
2 & $15^{* 1}$ & $0.9^{* 22}$ & 0.1 \\
3 & 96000 & 1120 & 0.05 \\
4 & 22500 & 600 & 0.2 \\
5 & 2000 & 400 & 0.3 \\
6 & $20^{* 1}$ & $1.2^{* 2}$ & 0.3 \\
\hline *1 $: \mathrm{Nm} / \mathrm{rad}, * 2: \mathrm{Nm} / \mathrm{rad} / \mathrm{s}$ & &
\end{tabular}

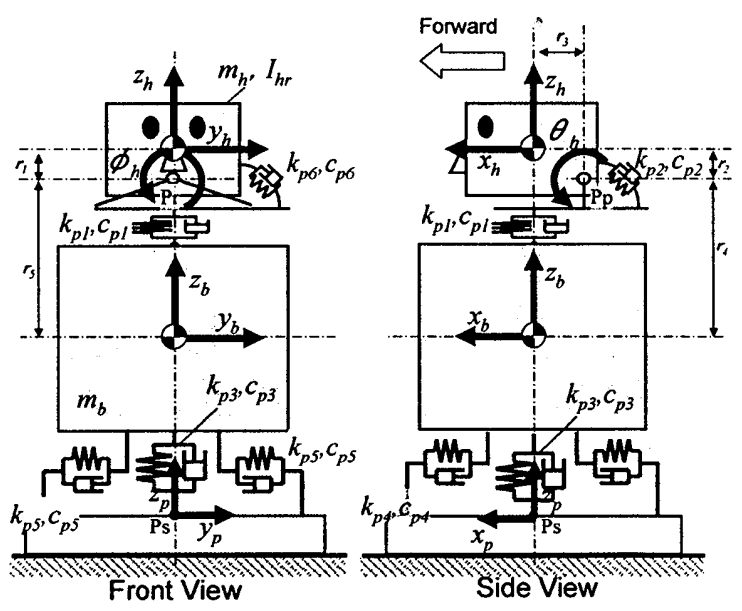

Fig.2 Passenger Model
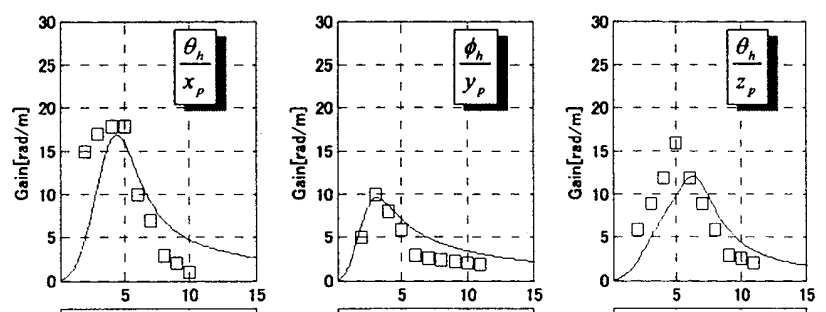

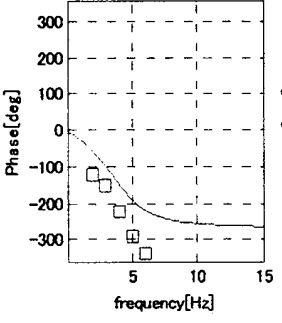

(a) $x_{p}$ input

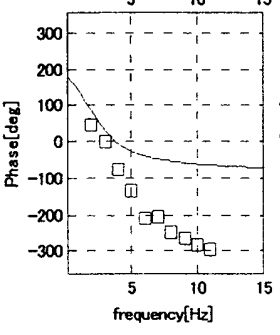

(b) $y_{p}$ input

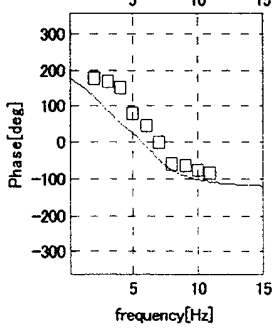

(c) $z_{p}$ input
Fig.4 Transfer function from seat to the head (Rotational motion, dot: Experiment ${ }^{10}$, Line: Model) 


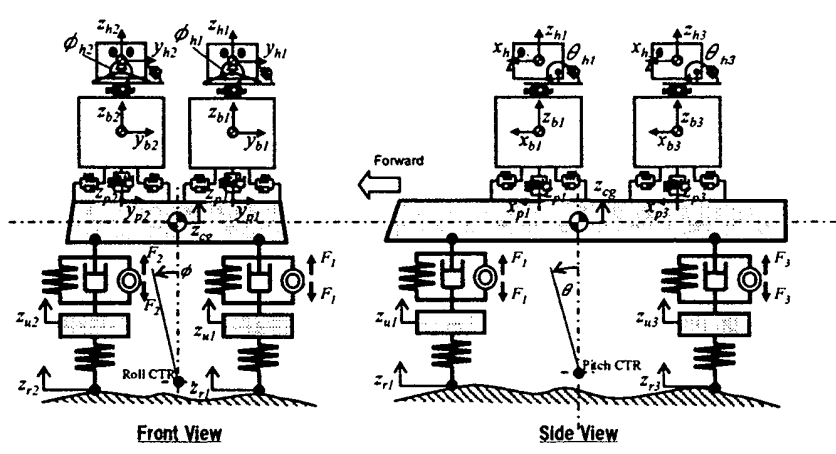

Fig.5 Vehicle-Passenger Model

$$
\begin{aligned}
& x_{p 1}=H_{p} \theta \\
& y_{p 1}=H_{r} \phi \\
& z_{p 1}=z_{c g}+y_{p 1} \phi-x_{p 1} \theta
\end{aligned}
$$

以上の運動方程式により, 次式の状態方程式を算出する.

$$
\dot{x}(t)=A_{p} x(t)+B_{p w} w(t)+B_{u} u(t)
$$

$$
\text { ここで }
$$

$$
\begin{aligned}
x(t) & =\left[z_{u 1} z_{u 2} z_{u 3} z_{u 4} z_{c g} \phi \theta \dot{z}_{u 1} \dot{z}_{u 2} \dot{z}_{u 3} \dot{z}_{u 4} \dot{z}_{c g} \dot{\phi} \dot{\theta} \cdots\right. \\
\left.x_{b 1} y_{b 1} z_{b 1} z_{h} \phi_{h 1} \theta_{h 1} \dot{x}_{b 1} \dot{y}_{b 1} \dot{z}_{b 1} \dot{z}_{h} \dot{\phi}_{h 1} \dot{\theta}_{h 1}\right]^{T} & \\
w(t) & =\left[z_{r 1} z_{r 2} z_{r 3} z_{r 4}\right]^{T} \\
u(t) & =\left[F_{1} F_{2} F_{3} F_{4}\right]^{T}
\end{aligned}
$$

\section{3. 制御系設部}

\section{1 外乱包含制御}

外乱に関する情報が全くない場合は外乱のダイナミクス を仮定するにあたって外乱の周波数帯域においてて白色雑音 $v$ とすることでロバストな設計となる.この限定した外乱の周 波数領域において外乱情報のフィードフォワード制御を生 かし，制御対象のフィードバック系と共に用いることで，よ り振動制御系の性能を向上できることが示されている ${ }^{12)}$.

ここでは,一定の周波数まで外乱のパワースペクトル密度 がフラットな特徴を有し，それ以上では低下するものとして， ローパス特性の伝達関数を有する成形フィルタによって生 成される有色雑音と仮定し，ローパス特性の伝達関数を有す る成形フィルタ式(7)によって生成される有色雑音と仮定し, 3.2 節で示す外乱の入力重みとする。

$$
\begin{aligned}
& Q_{w}\left\{\begin{array}{l}
\dot{x}_{w i}(t)=A_{w i} x_{w i}(t)+B_{w i} v_{w i}(t) \\
w_{w i}(t)=c_{w i} x_{w i}(t)
\end{array}\right. \\
& \frac{w(s)}{v(s)}=\frac{\varpi_{d}{ }^{2}}{s^{2}+2 \xi_{d} \varpi_{d} s+\varpi_{d}^{2}} \\
& \text { ただし, } \omega_{d}=50 \times 2 \pi, \quad \zeta_{d}=0.706 \text { とした. }
\end{aligned}
$$

\section{2 外乱包含 Ho制御}

3.1 節で述べたように，外乱包含制御において外乱モデル をフィードフォワードする際に, 仮定する入力外乱の周波数 領域外で応答レベルが覀化することが指摘されており，その 周波数領域外でのロバスト性を向上させることが必要であ る. そのため, 仮定した入力外乱の周波数領域外を外乱モデ
ルと制御システムの拡大系全体の不確かさとみなし，ロバス 卜制御でその領域を考虑することを考える．また，外乱の影 響を抑えたい評価出力に対して周波数重みを用いることに よって外乱抑圧制御を行い，外乱抑圧制御とロバスト制御を 行う $\mathrm{H} \infty$ 制御理論 における混合感度問題を適用し，以下に本 制御器の具体的設計方法を示す.

H制御において，一般化プラントの設計にあたり，車 両-乗員モデルに路面外乱の加え, 制御量および制御入力の 周波数重みを次式のように表す.

$$
\begin{array}{r}
Q_{c}\left\{\begin{array}{l}
\dot{x}_{c}(t)=A_{c} x_{c}(t)+B_{c} x(t) \\
z_{c}(t)=c_{c} x_{c}(t)+D_{c} x(t)
\end{array}\right. \\
Q_{i}\left\{\begin{array}{l}
\dot{x}_{i}(t)=A_{i} x_{i}(t)+B_{i} u(t) \\
z_{i}(t)=c_{i} x_{i}(t)+D_{i} u(t)
\end{array}\right.
\end{array}
$$

ここで， $x_{c} ， x_{i}$ は制御量および制御入力の状態量， $z_{c} ， z_{i}$ は制御量のおよび制御入力に対する周波数重みの出力量を 表し，それらを含む一般化プラントは次式で表せる。

$$
\begin{aligned}
& \dot{x}_{g}(t)=A_{g} x_{g}(t)+B_{1} w_{g}(t)+B_{2} u(t) \\
& z(t)=C_{1} x_{g}(t)+D_{12} u(t) \\
& y(t)=C_{2} x_{g}(t)+D_{21} w_{g}(t)
\end{aligned}
$$

上式において, 外乱 $w_{g}(t)$ から評価量 $z(t)$ までの伝達関数 $G_{z w}$ の $\mathrm{H}$ ノルムは次式で表現される.

$$
\operatorname{miu}_{u}\left\|G_{Z W}\right\|_{\infty}=\sup _{w} \frac{\|z\|_{2}}{\|w\|_{2}}=: \gamma^{*}
$$

ただし, $\gamma$ *は H補償器により奏現される $\mathrm{H}$ 制御系の $\mathrm{H}$ のノルムの最小值であり, この時の $\mathrm{H}$ 補償器は次式である 11).

$$
\begin{aligned}
& \dot{x}_{k}(t)=A_{k} x_{k}(t)+B_{k} y(t) \\
& u(t)=C_{k} x_{k}(t)
\end{aligned}
$$

Hœ制御器も図示した一般化プラントが Fig.6であり，本 提案手法の制御量は，乗員モデルの頭部上下加速度，車体 の上下速度, 各輪のタイヤ変位, 各輪の発生推力である. Fig.7に示すようにそれぞれの制御量の評価重みは，頭部上 下加速度は頭部の共振付近である $6 \mathrm{~Hz}$ にピークをもつ乗員 の動きを抑え，ばね上速度に関しては低周波で車両の動き を抑え, タイヤ変位はばね下共振でタイヤの接地荷重変動 を抑え，極低周波での定常的な制御を防ぎ，無駄なエネル ギーの消費を防止するために推力に重みを設定している.

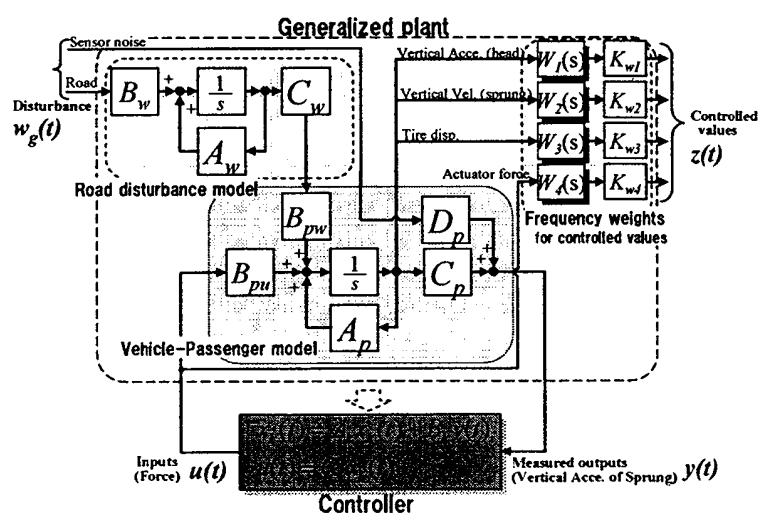

Fig.6 Generalized Plant 
また，本提案手法(手法 C)と比較のため, 制御量を頭部上 下 Gの変わりに車体の上下加速度 (手法 A), シートの上下加 速度(手法 B)とした $\mathrm{H}$ ○制御器も同様に設計し, 次章にて提 案手法(手法 C) との比較を行う。 なお, 周波数重み $w_{l}(\mathrm{~s}), w_{2}(\mathrm{~s})$, $w_{3}(\mathrm{~s}), w_{4}(\mathrm{~s}), k_{w 2}=400, k_{w 5}=0.125, k_{w f}=5000$, は手法 A,B,C のい ずれにおいても同様の值を用いている， $k_{w l}$ は，次章で記す.

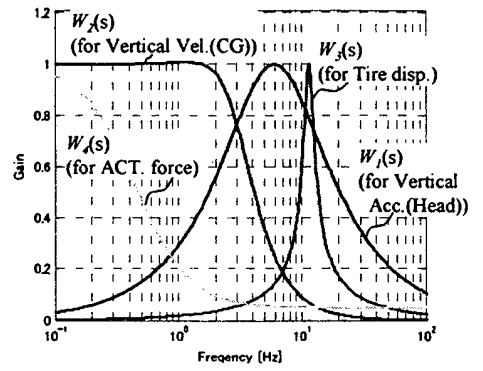

Fig.7 Frequency Weights for Controlled Value

\section{4. 数值シミュレーション}

\section{1 数值計算条件}

本研究では, 2 章で示した車両-乗員系のモデル(前席に 2 名 乗車)に, 3 章で設計した制御器を組み合わせ, The Math Work Inc.の MATLAB を用い, $1 \mathrm{msec}$ の時間刻みで計算を行った. なお，本モデルは理想的な条件とし，制御系設計モデルと 数値計算モデルは同様なモデルである.

\section{2 走行条件}

本シミュレーションは，車速 $60[\mathrm{~km} / \mathrm{h}]$ 一定走行時に ISO-8608 で定義された C クラス相当の PSD 特性となる路面を 10 秒間走 行したことを想定し, 数值計算を行った. なお車両は, 直線走行 を想定し，各輪への路面の入力は，それぞれ独立で与えている。 Fig.8 が作成した路面の PSD であり, Fig.9 が路面形状である.

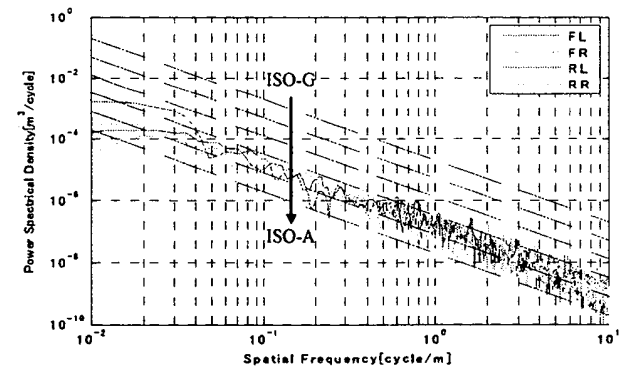

Fig.8 Power Spectral Density of Road Disturbance ${ }^{14)}$

\section{3 上下加速度夏みの结定}

各手法において, アクチュエータが発生する推力を同一条件 にするため, 四輪のアクチュエータが発生する推力絶対値の総 和の RMS が $1000 \mathrm{~N}$ となるように，各手法の制御重み $k_{w I}$ を調整 する. 手法 A, B, C の各 $k_{w l}$ は 244, 64, 60 である.

\section{4 部算結果と考察}

Fig.9の路面条件において, 各制御手法適用した場合の車両 および乗員の応答は Fig.10, アクチュエータが発生する推力の 応答が Fig.11 である. Fig.10 より, 車両重心の上下加速度は各 手法による差は少ないが，乗員頭部の上下加速度は本提案手 法による振動低減効果は明らかである. また, Fig.11 より, 手法 A はほぼ全車輪のアクチュエータが同相の力を発生しているの に対し，手法 B，C は左右で逆法の力を発生させることが増え， 積極的に車体のロールを使いながらシート位置での上下加速
度,さらには乗員頭部の上下加速度を低減させていることがわ かる.

手法 A と手法 C を適用した場合において，車両前方方向から 見た前席二人の着座位置, 胴体, 頭部の各上下および左右方 向の加速度の結果を Fig.12 に示す. 手法 C は, 助手席乗員の 頭部上下加速度を制御量としているため，手法 A に比べ乗員 の頭部举動が小さいことがわかる. また，手法 C は制御量とした 助手席頭部の上下加速度が同手法の運転席頭部の上下加速 度よりも小さいだけでなく, 胴体相当の動きも抑制していることが 分かる.

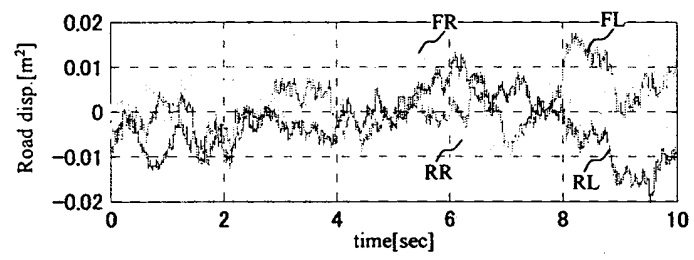

Fig.9 Road displacement
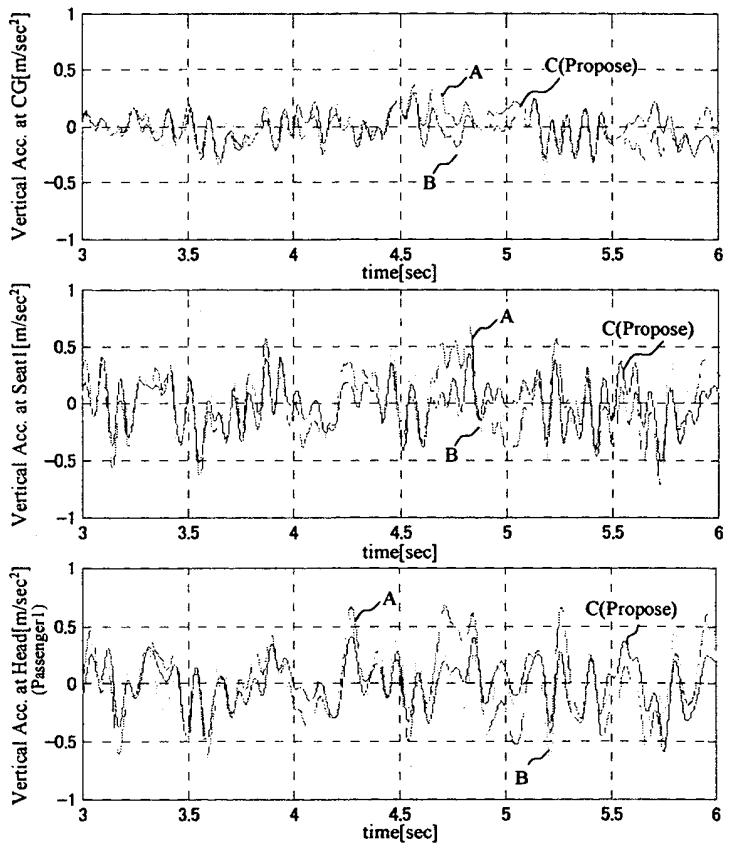

Fig. 10 Vehicle and Passenger's behavior
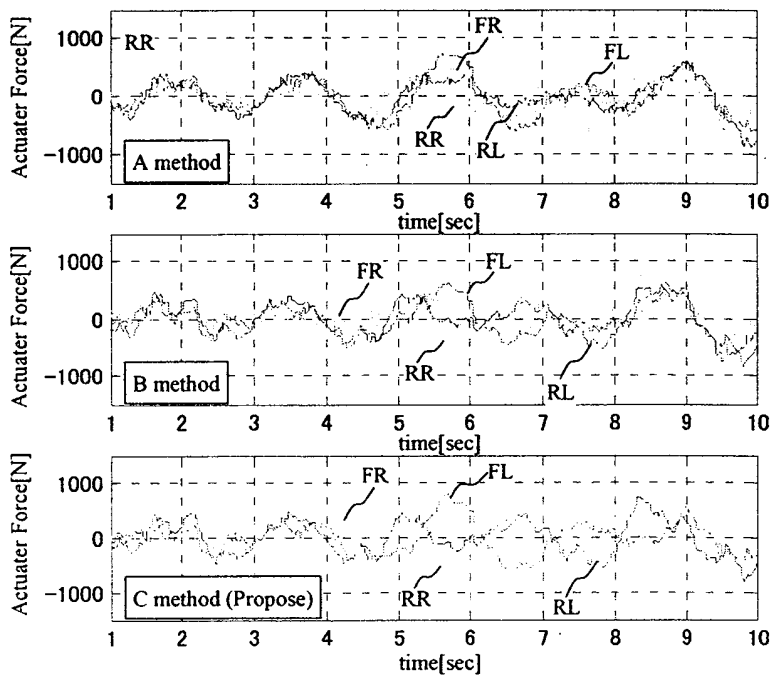

Fig.11 Actuator Force 


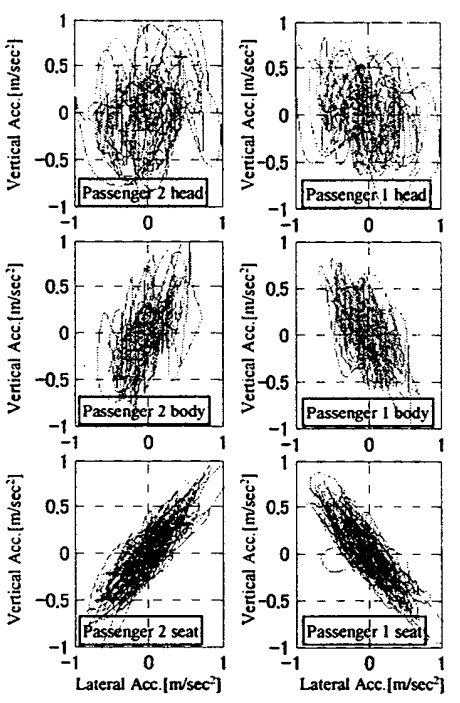

(a) A method
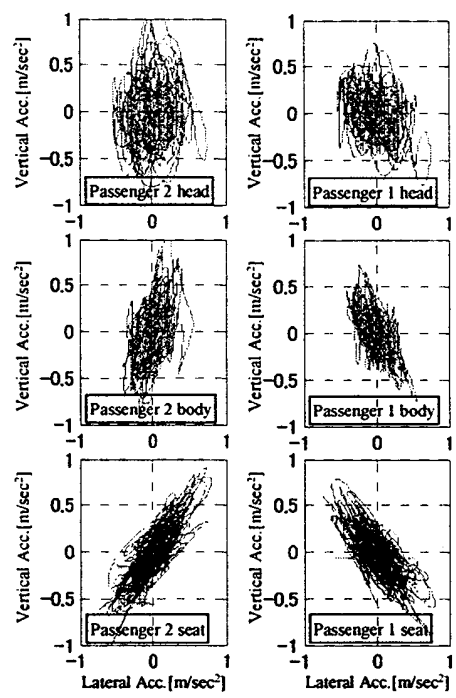

(b) C method (propose)

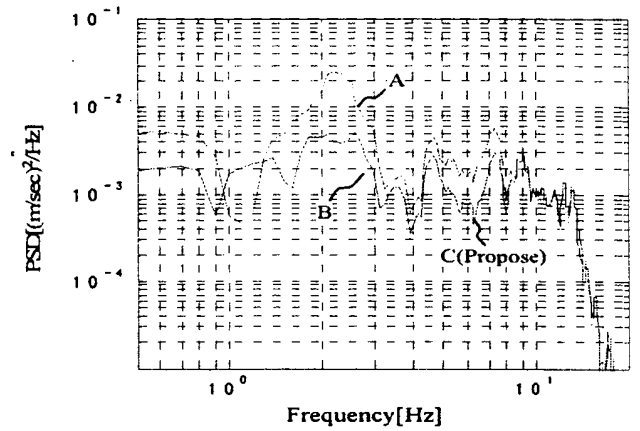

(a) Vertical Acceleration (Passengerl' head)

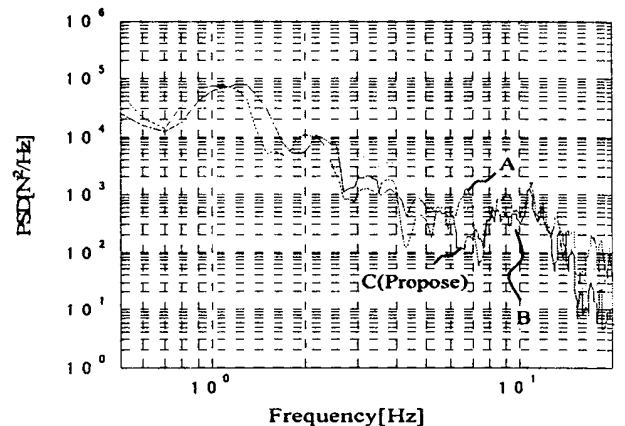

(b) Actuator force

Fig.13 Power Spectral Density

上下加速度の PSD を Fig13 に示す. 頭部の共振がある 4 7 $\mathrm{Hz}$ の帯域においては, 手法Cが最も制振効果が高いにも関わらず, 推力の PSD は同周波数帯域においては必ずしも最む推力が高 いわけではない. そのことから, 特に同周波数においては限ら れた推力においても制御効果を期待することが可能であるとい える.

\section{5. 結}

本研究では, アクティブサスペンションを用いて，路面の凹凸 による乗員の動きをより低減させることを目的とし, 乗員のダイナ ミクスを含む車両-乗員系を構築し, 乗員(助手席)の頭部の上下 加速度を評価量のひとつとする制御系を提案した。提案手法は， 従来手法に比べ, アクチュエータが発生する単位推力(RMS へ 一ス)に対する制御效果が大きく, 消費エネルギー的にも効率 の良い制御手法であり,その有効性を示寸ことができた.

\section{䒧考 文 献}

1) 池田, 村田, 大作, 富田, 新堿衰力制御の開発-仮 想口ルダンパ制御と非線形 Ho制御-, TOYOTA Technical Review, (1999), Vol.49. No.2, pp.88-93

2) 小瀬村, 高橋, 吉田, 走行状況を考慮した自動車用セミアク ティブサスペンションの総合的制御系設計, D\&D, (2008)

3) N. Itagaki, T. Fukao, M. Amano, N. Ichimaru, T. Kobayashi, and T. Gankai, Semi-Active Suspension Systems based on Nonlinear Control, AVEC(2008), pp684-689

4) 玉置, 吉村, 着座時の人体振動に与えるシートの影響, $\mathrm{D} \& \mathrm{D},(2007)$

5) 小泉, 辻内, 阿部, 二宮, 山崎, 人体振動特性を考慮した 乗心地性能向上のための評価法確立, D\&D, (2007)

6) G.J.Stein and P.Mucka, Theoretical investigation of a linear planar model of a passenger car with seated people, IMechE, Part D: J. Automobile Eng., (2003), Vol.217, pp.257-268

7) Masahiro Oya, Yasutaka Tsuchida, and Qiang Wang, Robust Control Scheme to Design Active Suspension Achieving the Best Ride Comfort at Any Specified Location on Vehicles, AVEC, (2008), pp.690-695

8) E. Guglielmino, T Sireteanu, C. Stammers, G. Ghita, M Giuclea, Semi-Active Suspension Control-Improved Vehicle Ride and Road Friendliness, Springer, (2008)

9) ISO-5982:2001, Mechanical vibration and shock -Range of idealized value to characterize seated body biodynamic response under vertical vibration, International Organization for Standardization

10) 玉置, 吉村, 鈴木, 多方向振動入力を受ける人体のダイナミ クスとモデリング(三軸加振実験による人体の動特性の把握), 機論, (1998), 64 巻, 617 号

11) 玉置, 吉村, 谷本, 頭部の回転に着目した人体のダイナミク スとそのモデリング, 機構論, (1996), No.96-5 I, pp. $522-525$

12) 岡本, 吉田, 自動車用セミアクティブサスペンションの外乱 包含双線形最適制御, 機論, (2000), 66 巻, 650 号

13) K.Glover, J.C.Doyle, State-space Formula for All Stabilizing Controllers that Satisfy an $\mathrm{H}_{\infty}$-norm Bound and Relations to Risk Sensitivity, Systems \& Control letters, (1988), 11, pp167-172

14) ISO-8608:1995, Mechanical vibration - Road surface profiles - Reporting of measured data, International Organization for Standardization 